\title{
The Belief Systems of Protesting College Students
}

\author{
Monica D. Blumenthal ${ }^{1}$
}

Received December 1, 1972

\begin{abstract}
A group of 29 college students who had been arrested or nominated as having participated in a street disturbance aimed at producing social change were interviewed. The interview schedule was highly similar to one which had been used to investigate attitudes toward violence in a random, representative sample of American men. The data collected from the arrestees are compared with data from college students in the national sample. This study shows that the arrestees are more likely to think that violence is necessary to produce social change than are college students generally, and are more likely to believe that existing social institutions are inadequate. As a group, the arrestees are more identified with white student demonstrators and black protestors than are college students generally. The arrestees are also likely to regard the police as untrustworthy, looking for trouble, and apt to dislike people like themselves. In addition to the negative attitudes toward the police held by the student arrestees, they are more likely to regard police actions as violence land hence provocative) than are other college students. The arrestees are far more likely than other college students to cleave to humanistic values. However, most of the differences between the arrestees and other American college students could be predicted from a general model of the justification of violence, so that it appears that the student activists' beliefs differ not so much in kind from those of other Americans as they do in degree.
\end{abstract}

\section{INTRODUCTION}

Our group has been engaged in the study of attitudes toward violence since 1968. During the course of our studies, we have been particularly concerned

This research was funded by NSF Grants GS 2424 and GS 28295 under a project codirected by Monica D. Blumenthal, Robert L. Kahn, and Frank M. Andrews.

${ }^{1}$ Survey Research Center, Institute for Social Research, The University of Michigan, Ann Arbor, Michigan. Currently Program Director at the Institute for Social Research in the Survey Research Center, and Associate Professor of Psychiatry at the University of Michigan Medical School. Obtained M.D. from the University of Michigan Medical School and Ph.D. in physiology from the University of California, Berkeley. Currently engaged in social psychological research, with main interests focused on violence and the epidemiology of depressive disorders. Psychiatric interests are biologically oriented and focused on adult psychiatry. 
with attitudes toward two specific types of violence, namely, violence used as a means of maintaining social control and violence used as a means of prducing social change. Our primary motive in studying attitudes toward violence has been the belief that attitudes are related to behaviors, and that consequently the measurement of attitudes would prove a useful social indicator.

A crucial link in developing the measurement of attitudes toward violence as a social indicator is to establish the relationships between such attitudes and violent behaviors. These relationships are complex. It is part of the human condition for people to do things which are contrary to their beliefs, and it is also true that people sometimes fail to act in accordance with their beliefs. Nevertheless, such permutations of what might be expected are seen as deviations, and it seems reasonable to suppose that on the whole people are more likely to act in accordance with their beliefs than in opposition to them.

How violent behaviors relate to attitudes toward violence is also complicated because an element of chance is involved in the commission of violent acts. Whether or not an individual commits violence is determined at least in part by whether he has the opportunity to do so. Some environments and circumstances are more conducive to violence than others. For example, it is unlikely that a person would behave violently in a Trappist monastery, while it is quite likely that the same person would commit violence if he were a soldier in the front line of combat. It is true, of course, that people with specific attitudes toward violence may gravitate toward environments which increase or decrease the likelihood of violence. Nevertheless, chance plays a role in determining whether or not an individual participates in violence such as riots (Campbell and Schuman, 1968). More than willingness to join is required; unless he has the wherewithal required to begin a riot de novo, the potential rioter is most likely to become a participant if a riot occurs in his immediate vicinity, or if he hears of one within commuting distance. This element of chance increases the difficulty of predicting violent behaviors from attitudes, but if attitudes are related to behaviors as we expect, those who have demonstrated their willingness to behave violently should hold attitudes congruent with their actions. Specifically, they should hold attitudes favoring violence of the type committed.

Using this line of reasoning, it was hypothesized that people who had participated in actions aimed at producing social change violently would hold more positive attitudes toward this type of violence than members of the population at large. Consequently, in the summer of 1969 we interviewed a small group of students who had been arrested following a disturbance meant to produce social change. The interview schedule was almost identical with one that had been used to survey attitudes toward violence in a representative national sample of American men that same summer (Blumenthal et al., 1972).

The major hypothesis underlying the study of the students was that participants in the disturbance would show more positive attitudes toward 
violence for social change than college students in the national sample. Moreover, the theoretical model on which the national survey was based postulated that attitudes toward violence were determined by three major psychological factors: (1) the individual's personal values, (2) the extent to which the individual identified with the contenders in violence, and (3) the acts and behaviors the individual labeled "violence." The national data indicated that these psychological factors postulated by this model were substantially correlated with attitudes toward violence (Blumenthal, 1972).

Rokeach (1960) points out that belief systems are organized according to a central peripheral dimension. Central regions represent "primitive" beliefs which are axiomatic in character. Peripheral beliefs are derived from these. In our study of violence, we regard values and identification with the contenders as having a more axiomatic nature and attitudes toward violence as being more derivative in character. The model assumed that values and identifications are central beliefs which are causal in relationship to attitudes toward violence. If this is the case, it should follow that persons demonstrating specific violent or nonviolent attitudes and behaviors should have predictable values, predictable identifications with the contenders in the violence, and should hold predictable beliefs about what constitutes "violence." So, a set of secondary hypotheses was derived from the model and the supporting national data. These hypotheses stated that the student arrestees should differ from American college students in specified ways. These hypotheses were derived from the model indicated above, as it has been substantiated by the national data. The national data were complicated because there were major interactions due to race and education in the prediction of attitudes toward violence for social change. For this reason, the hypotheses for the student arrestees were based on the data analysis of those who had at least some college education.

Interest in the student unrest and activism which occurred during the late 1960s has been considerable (Horn and Knott, 1971). Earlier studies of student activists emphasized the socialization and uniqueness of these young people. Many activists were children of highly educated parents, who were often professionals. The parents of activists were found to be more liberal in outlook than the parents of nonactivist students, and it was thought that activists were often closer to their parents than their college peers (Watts and Whittaker, 1966; Westby and Braungart, 1966; Flacks, 1970; Clarke and Egan, 1972). These findings tend to emphasize the special and unique character of the student activists. More recently, however, it has been suggested that participation in the student movement is becoming more broadly based (Mankoff and Flacks, 1971). The national data provide an opportunity for comparing the belief systems of student activists with the beliefs of other American men. This work indicates that the belief system of the particular group of student activists studied is highly similar to that of college-educated American men generally, and that the beliefs of the activists appear to vary not so much in kind as in degree. 


\section{RESULTS}

The students interviewed were arrested or identified as participating in a disturbance on several consecutive nights in the summer of 1969 near the University of Michigan campus. These students had been part of a larger crowd attracted to the attempt, mostly of "street people" and high school youths, to "liberate" a street of several blocks adjoining the campus area. The area is heavily concentrated with student rooming houses and apartments, stores, and restaurants, and the effort to take over the area attracted a predictable larger secondary crowd of interested onlookers and fringe participants. The disturbance itself lasted 3 days. There were attempts at dispersal and control of the crowd by university representatives and city officials; there was also the use of considerable force by the police from the office of the county sheriff. During the disturbance, a number of young people were arrested and charged with a variety of offenses, including property damage and physical assault. (Most of these charges were later dropped.) Much of the rhetoric used by the crowd leaders was revolutionary in character. Specific demands for change were made. We assumed that "liberating" a street might be regarded as a social change of sorts and that the entire action might be regarded as a form of violence for social change.

Twenty-nine college students were interviewed, of whom 20 had been arrested by the police. The remainder were nominated by the arrestees as having been active participants in the disturbance. For the sake of convenience, the entire group will be referred to as the "student arrestees." Most of the 29 students attended the University of Michigan, a large Midwestern university, while a few attended a smaller state university nearby. The comparison group consisted of those respondents who were college students in our 1969 national survey, conducted on a random representative sample of 1374 men from 16 to 64 years of age in the same summer as the disturbance (Blumenthal et al., 1972).

The families of the student arrestees were highly educated. Twenty-eight percent of the fathers had had at least some graduate education compared to $9 \%$ of the fathers of college students in the national sample. Sixty-six percent of the fathers of the arrestees had had at least some college education, compared to $29 \%$ of the fathers of college students generally. Twenty-five percent of their mothers had had some graduate education, compared to $2 \%$ of those of college students in the national sample. Whether the high education of the parents of the arrestees is a reflection of the fact that so many of the student arrestees were attending a prestigious university is not certain, but it seems likely even when this circumstance has been taken into account that the arrestees were disproportionately the children of the highly educated. Interestingly enough, there was essentially no difference in the family income of the arrestees and college students in the national sample. 
Many workers (Watts and Whittaker, 1966; Mankoff and Flacks, 1971; Clarke and Egan, 1972) have stated that atheists and Jews are overrepresented among student activists. The student arrestees showed a similar pattern; they were more likely to describe themselves as atheists or agnostics (24\%) than were college students in the national sample (2.6\%); furthermore, $14 \%$ were Jewish compared to $8 \%$ of college students in the national sample. The student arrestees also scored lower than the national sample of college students on an index of religiosity which combined Sunday school attendance and how religious-minded the respondent thought himself. Fifty-two percent of the arrestees fell in the least religious category compared to $17 \%$ of college students generally. Thus the demographic characteristics of the student arrestees are very similar to those reported for student activists by other studies.

The major hypothesis of this study was that participants in the street disturbance would show more positive attitudes toward the use of violence to produce social change than would college students in the national sample. Attitudes toward violence for social change were measured by a set of five questions which inquired to what extent the respondent thought property damage or personal injury necessary to produce change at a reasonable rate. These questions were asked once in respect to the amount of violence thought necessary to bring changes of the type needed by students, once in respect to changes needed by blacks, and once in respect to change in general. The responses to these questions were combined into a summary scale, the Violence for Social Change Index. The higher the score on the Index, the more the respondent agreed that violence was necessary to bring about change. (Details of index construction of this scale and all others are given in Blumenthal et al., 1972.)

As predicted, the student arrestees scored significantly higher on the Violence for Social Change Index than did college students in the national sample (Table I). Moreover, college students in the national sample were themselves more apt to agree that violence is necessary to bring about social change at a reasonable rate than were men of similar education who were not in school at the time. The majority of the latter were in the lowest category of the Violence for Social Change Index; only $4 \%$ of the student arrestees fell in this category. These data support the notion that attitudes are apt to be congruent with behaviors. It is possible, of course, that these positive attitudes toward violence were formed after the disturbance as rationalizations of behaviors that had already occurred. But it is equally possible that they existed prior to the disturbance and influenced the behaviors of the students.

Student unrest has been attributed to the desire of the young to bring about in fact the egalitarian ideals on which this government is based in principle (Report of Campus Unrest Commission, 1970), and many researchers have commented that student activists are disenchanted with existing social policies 
Table I. Percentage Responses to the Violence for Social Change Index for Student Arrestees, College Students and Nonstudents with Some College or More

\begin{tabular}{lccc}
$\begin{array}{l}\text { Violence for } \\
\begin{array}{c}\text { Social Change } \\
\text { Index }\end{array}\end{array}$ & $\begin{array}{c}\text { Student arrestees } \\
\text { (participants in U. of } \mathrm{M} \\
\text { street disturbance) } \\
(N=27)\end{array}$ & $\begin{array}{c}\text { College students } \\
\text { (national sample) } \\
(N=63)\end{array}$ & $\begin{array}{c}\text { Non-students } \\
\text { with some college } \\
\text { (national sample) } \\
(N=304)\end{array}$ \\
\hline Low 1 & 4 & 35 & 52 \\
$2-3$ & 37 & 38 & 34 \\
High $4-7$ & 59 & $100 \%$ & $\frac{14}{100 \%}$ \\
Total & $100 \%$ & & \\
\\
$P<0.001$ (Kolmogorov-Smirnov test) that college students differ from the student \\
arrestees.
\end{tabular}

and institutions (Lipset, 1968; Keniston and Lerner, 1968; Morse and Peele, 1971). Data from the national survey indicate that there is a general relation between cynicism about existing social institutions and unrest. Among men who have some college education, those with greater doubts are more likely to express the belief that violence is necessary to bring about social change than are those who are less cynical about existing institutions. Specifically, the data show that those who believe the courts are unfair are more likely to think violence is necessary to bring about social change than are those who do not. Similarly, those who are more agreed with the propositions that social problems such as unemployment, poverty, discrimination, and a poor education cause violence are also more likely to think violence necessary to bring about social change than are those who do not share such beliefs. If the student arrestees have belief systems similar to those of other American men, one would expect that the former would be more likely to think the courts unfair than college students generally do. Table II shows this to be the case. Seventy-nine percent of the student arrestees fell in the lowest category of the Court Fairness Index, indicating that more than three-fourths believed the courts treat rich better than poor, white better than black, in addition to holding the belief that they themselves are unlikely to be treated fairly by the courts. Of course, the majority of the student arrestees had been arrested at the time they were interviewed and may have had some contact with the courts. It may be that their negative attitudes toward the courts were formed as a result of their experiences. Nevertheless, their beliefs were in the predicted direction.

The student arrestees did not show a greater belief that social problems cause violence than did other college students (Table III). The lack of a significant difference in the predicted direction may be due to the fact that the measure is very heavily skewed; in 1969 from 71 to $89 \%$ of all American men believed that such problems contribute to violence. 
One last question in the interview can contribute some insight to how the student arrestees viewed social institutions:

Think of people who run things like the government, big business, and such. Is the way they are trying to run things generally favorable for you, bad for you, or somewhere in between? [If in between] Would you say the things they are trying to do are more good than bad for you, more bad than good, or just about the same?

Table IV shows that the student arrestees did not think well of the establishment. Indeed, altogether $79 \%$ of them thought that the way things were being run was on the bad side of neutral. In this they differed sharply from most American college students, whose opinions were almost identical with those of college-educated men generally. It should be noted that the beliefs of the student arrestees are congruent with what was predicted on the basis of data collected from college-educated men rather than from students. These data suggest that the beliefs of the student arrestees are closely related to beliefs held by college-educated adult men generally. These beliefs are also what might have

Table II. Percentage Responses to the Court Fairness Index ${ }^{a}$ for Student Arrestees and College Students

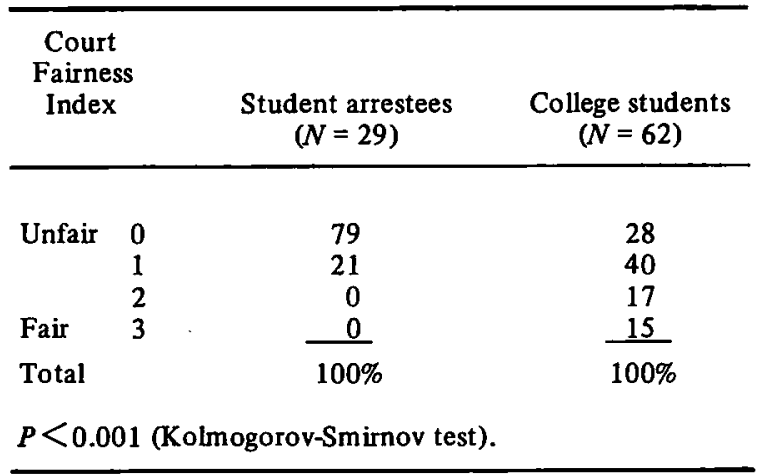

${ }^{a}$ The Court Fairness Index is based on responses to the following questions:

1. Some people have told us the courts nowadays treat some people better or worse than others. Do you think that rich people and poor people are likely to be treated the same by the courts or not?

2. Do you think that white people and black people are likely to be treated the same by the courts or not?

3. Do you think the courts treat people like yourself better or worse than others, or about the same?

The higher the score on the Index, the more the respondent thought the courts were fair. 
Table III. Percentage Responses to the Social Causes Index ${ }^{Q}$ for Student Arrestees and College Students

\begin{tabular}{l}
$\begin{array}{l}\text { Social Causes } \\
\text { Index }\end{array}$ \\
\hline \\
$\begin{array}{l}\text { Don't lead to } \\
\text { violence }\end{array}$ \\
Lead to violence \\
Total
\end{tabular}

been expected on the basis of what was previously known about student activism. The data imply that the beliefs of student activists are not idiosyncratic to a small group of unique individuals, but an integral part of American life.

The model on which the national survey was based predicted that the extent to which the individual identified with the contenders in a violent action would serve as an important factor in determining the justification of violence.

Table IV. Percentage Responses on Identification with the Establishment for Student Arrestees and College Students

\begin{tabular}{lrcc}
\hline & $\begin{array}{c}\text { Student arrestees } \\
(N=28)\end{array}$ & $\begin{array}{c}\text { College students } \\
(N=60)\end{array}$ \\
\hline & & & 17 \\
Generally bad & 1 & 54 & 51 \\
Generally favorable & 5 & $\frac{39}{100 \%}$ & $\frac{32}{100 \%}$ \\
Total & & $100 \%$ & \\
$P<0.001$ (Kolmogorov-Smirnov test). & \\
\hline
\end{tabular}


This expectation was borne out by the data. Specifically, among the collegeeducated the extent to which individuals identified with the contenders in the violence accounted for $44 \%$ of the variance in the Violence for Social Change Index. The more the individual identified with the implicit victim of the violence, the less likely he was to be favorable to the use of violence against that victim. The more the respondent identified with the presumed aggressor in the violence, the more likely he was to justify such violence. If the attitudes of the student arrestees were also influenced by identification with the contenders in the violence, the arrestees should have predictable beliefs about those involved in the violence.

In the scenarios in the interview schedule which described violence for social change, the implicit aggressors were "white student demonstrators" and "black protestors," while the implicit victims were the police. In the national data, those who were highly identified with "white student demonstrators" were more likely to have high scores on the Violence for Social Change Index than those who were not. In addition, those who held negative views of the police were more likely to think violence necessary to produce social change than those who did not. These data led to the hypotheses that the student arrestees should show greater identification with "white student demonstrators" and less identification with police than do college students in the national sample. Table $V$ shows the first hypothesis to be confirmed. The student arrestees gave significantly more positive responses to three of the four items used to measure identification with "white student demonstrators" than did American college students generally. The arrestees appeared to be highly identified with "white student demonstrators." This is hardly surprising since they might properly class themselves under that rubric.

A similar trend holds for identification with black protestors. The student arrestees showed significantly higher identification than did college students nationally on two of the four items, and a strong trend in the anticipated direction on one of the remaining two. These data cannot be explained by the students "belonging" to the group. Nevertheless, they were predictable by the model of attitudes toward violence.

A second hypothesis concerning identifications generated by the model and the national data was that the student arrestees would show low levels of identification with the police (Table VI). As a group, the arrestees felt that the police were apt to be "looking for trouble," and that "almost all" or "many" police would be apt to dislike persons like themselves. Sixty-four percent of the student arrestees, compared to $17 \%$ of college students in the national sample, thought one couldn't be too careful in dealing with the police, and $89 \%$ of the student arrestees, compared to $14 \%$ of college students generally, thought that if the police achieved their goals, life was likely to change for the worse.

The importance of the police as a focal point for negative attitudes toward 
Table V. Percentage Responses to Items Measuring Identification with White Student Demonstrators for Student Arrestees and National Sample of College Students

On the whole, would you say that most white student demonstrators are trying to be helpful, or that they are looking for trouble, or that they aren't one way or the other?

Looking for trouble

Not one way or the other

Trying to be helpful

Total

\begin{tabular}{cc}
$\begin{array}{c}\text { Student arrestees } \\
(N=28)\end{array}$ & $\begin{array}{c}\text { College students } \\
(N=62)\end{array}$ \\
\hline 7 & 10 \\
18 & 51 \\
$\frac{75}{100 \%}$ & $\frac{39}{100 \%}$
\end{tabular}

$P<0.001$ (Kolmogorov-Smirnov test).

Think of how white student demonstrators think of people like yourself. Do you think that none dislike people like yourself, only a few, many, or almost all dislike people like yourself?

\begin{tabular}{lcc} 
& $\begin{array}{c}\text { Student arrestees } \\
(N=28)\end{array}$ & $\begin{array}{c}\text { College students } \\
(N=61)\end{array}$ \\
\cline { 2 - 3 } Almost all & 7 & 5 \\
Many & 7 & 12 \\
A few & 79 & 77 \\
None & $\frac{7}{100 \%}$ & $\frac{6}{100 \%}$ \\
Total &
\end{tabular}

Not significant (Kolmogorov-Smirnov test).

Would you say that most white student demonstrators can be trusted, or that you can't be too careful in dealing with them?

$\begin{array}{cc}\text { Student arrestees } & \text { College students } \\ (N=28) & (N=62)\end{array}$

Can't be too careful in dealing with them

Don't know

Can be trusted

Total

\begin{tabular}{cc}
\hline 7 & 33 \\
7 & 9 \\
86 & 58 \\
\hline $100 \%$ & $100 \%$
\end{tabular}

$P<0.02$ (Kolmogorov-Smirnov test).

If white student demonstrators get the things they want, do you think your life will change? If "will change": Do you think your life will change for better or worse?

\begin{tabular}{lcc} 
& $\begin{array}{c}\text { Student arrestees } \\
(N=26)\end{array}$ & $\begin{array}{c}\text { College students } \\
(N=53)\end{array}$ \\
\cline { 2 - 3 } Worse & 4 & 18 \\
Won't change & 11 & 39 \\
Better & $\frac{85}{100 \%}$ & $\frac{43}{100 \%}$ \\
Total & & \\
$P<0.001$ (Kolmogorov-Smirnov test). & & \\
\hline
\end{tabular}


Table VI. Percentage Responses to Items Measuring Identification with Police for Student Arrestees and National Sample of College Students

On the whole, would you say that most policemen are trying to be helpful, or that they are looking for trouble, or that they aren't one way or the other?

\begin{tabular}{lcc} 
& $\begin{array}{c}\text { Student arrestees } \\
(N=27)\end{array}$ & $\begin{array}{c}\text { College students } \\
(N=63)\end{array}$ \\
\cline { 2 - 3 } & 41 & 7 \\
Looking for trouble & 18 & 18 \\
Trying to be helpful & $\frac{41}{100 \%}$ & $\frac{75}{100 \%}$ \\
Total & & \\
$P<0.01$ (Kolmogorov-Smirnov test). & & \\
\hline
\end{tabular}

Think of how policemen think of people like yourself. Do you think that none dislike people like yourself, only a few, many, or almost all dislike people like yourself?

\begin{tabular}{lcc} 
& $\begin{array}{c}\text { Student arrestees } \\
(N=29)\end{array}$ & $\begin{array}{c}\text { College students } \\
(N=62)\end{array}$ \\
\cline { 2 - 3 } Almost all & 28 & 8 \\
Many & 48 & 10 \\
A few & 21 & 61 \\
None & $\frac{3}{21}$ \\
Total & $100 \%$ & $100 \%$ \\
$P<0.001$ (Kolmogorov-Smirnov test). & & \\
\hline
\end{tabular}

Would you say that most policemen can be trusted, or that you can't be too careful in dealing with them?

Student arrestees

$(N=28)$
College students

$(N=63)$

Can't be too careful in

dealing with them

$\begin{array}{cc}64 & 17 \\ 0 & 2 \\ 36 & \frac{81}{100 \%}\end{array}$

Don't know

Can be trusted

Total

$p<0.001$ (Kolmogorov-Smirnov test).

If the police get the things they want, do you think your life will change? If "will change": Do you think your life will change for the better or worse?

\begin{tabular}{lcc} 
& $\begin{array}{c}\text { Student arrestees } \\
(N=28)\end{array}$ & $\begin{array}{c}\text { College students } \\
(N=55)\end{array}$ \\
\cline { 2 - 3 } Worse & 89 & 14 \\
Won't change & 7 & 54 \\
Better & $\frac{4}{100 \%}$ & $\frac{32}{100 \%}$ \\
Total & & \\
$P<0.001$ (Kolmogorov-Smirnov test). & & \\
\hline
\end{tabular}


the government held by minority groups has been commented on by many social scientists (Marx, 1970). Much of this discussion has focused on the relationship between the police and the black community. However, there has been some recognition of the importance of the relationship between police and students in the escalation of student disturbances (Report of Campus Unrest Commission, 1970). Nevertheless, attitudes of students toward police have received relatively little attention from social scientists. Our data indicate that students who participate in disturbances may hold the same negative views of police that are characteristic of other dissenting minorities. At least, such is the case in this small group of activists. These findings can hardly be regarded surprising; however, they do provide some evidence in an area that has been relatively neglected in research on student activism.

Another major factor specified in our model predicting attitudes justifying violence was the nature of the respondents' rhetoric. In the national data, variables related to rhetoric accounted for $30 \%$ of the variance in the Violence for Social Change Index among college-educated men. The more certain police actions ("shooting looters," "beating students," and "frisking people") were regarded as violence, the more likely the individual was to think violence necessary to bring about social change. This finding leads to the prediction that the student arrestees should be more likely to find such police actions violent than college students in the national population. Table VII shows that this is the case. The data imply that the student arrestees were more likely than other

Table VII. Percentage Responses to the "Are Police Acts Violence?" Index ${ }^{a}$ for Student Arrestees and College Students

\begin{tabular}{ccc}
\hline $\begin{array}{c}\text { Police Acts } \\
\text { Violence Index }\end{array}$ & $\begin{array}{c}\text { Student arrestees } \\
(N=29)\end{array}$ & $\begin{array}{c}\text { College students } \\
(N=63)\end{array}$ \\
\hline No & & \\
1 & 0 & 9 \\
2 & 10 & 43 \\
3 & 31 & 34 \\
Yes & $\frac{59}{100 \%}$ & 14 \\
4 & & $100 \%$ \\
Total & \\
$P<0.001$ (Kolmogorov-Smirnov test).
\end{tabular}

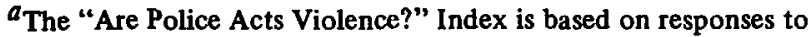
the questions:

Do you think of police beating students as violence?

Do you think of police shooting looters as violence?

Do you think of police stopping to frisk people as violence?

The higher the score on the Index, the more the respondent defined these acts as "violence." 
Americans to regard police actions as offensive. When the word "violence" is applied to a behavior, it is likely to mean that the behavior is seen as "bad," "unnecessary," and "worthless" (Blumenthal et al., 1972). Such being the case, one can infer that the student arrestees were particularly apt to regard police actions as provocative. It is well known that police-student interactions may result in escalating violence (Flacks and Mankoff, 1970; Nelson, 1970). One crucial variable in this phenomenon may be the tendency of student activists to view police actions as "violence" to a greater extent than do other Americans. Recognition of this fact should prove helpful in the management of disturbances.

The national data showed that among college-educated men the less protest activities are regarded as violence, the more the individual was likely to believe violence necessary to bring about social change. This suggests that the student arrestees would be less likely to think that actions of dissent such as draft-card burning, sit-ins, or student protests were violent than college students in the national sample. Table VIII shows that this is the case. Eighty-three percent of the student arrestees thought all three of those actions were "not violence," an opinion shared by only $42 \%$ of college students generally.

The student arrestees also showed a more positive ideological stance toward violence per se than did college students in the national sample. When asked to rank "violence" between "good" and "bad," "necessary" and "unnecessary," "valuable" and "worthless" on a semantic differential, the student arrestees were far more apt to view "violence" in a favorable light than were college students in the national sample (Table IX). Their rhetoric matched their behavior.

Table VIII. Percentage Responses to the "Is Protest Violence?" Index $a$ for Student Arrestees and College Students

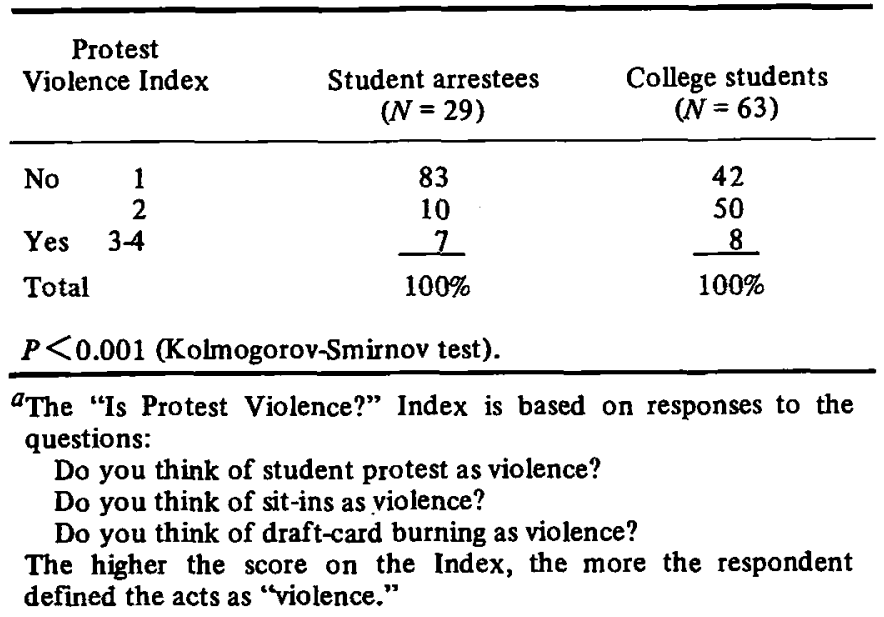


Table DX. Percentage Responses to the Evaluative Index for Student Arrestees and College Students

\begin{tabular}{lccc}
\hline $\begin{array}{c}\text { Evaluative } \\
\text { Index }\end{array}$ & $\begin{array}{c}\text { Student arrestees } \\
(N=27)\end{array}$ & $\begin{array}{c}\text { College students } \\
(N=63)\end{array}$ \\
\hline & 1 & 96 & 21 \\
Good-valuable-necessary & 2 & 4 & 22 \\
& 3 & 0 & 25 \\
& 4 & 0 & 17 \\
Bad-worthless-unnecessary & 5 & 0 & 15 \\
Total & & $100 \%$ & $100 \%$ \\
$P<0.001$ (Kolmogorov-Smirnov test). & & \\
\hline
\end{tabular}

The third important set of variables specified by our model of the justification of violence is personal values. Among the college-educated, these accounted for $14 \%$ of the variance in the Violence for Social Change Index. Specifically, among the college-educated, those who were less retributive were more likely to think violence necessary for bringing about social change than those who were more inclined to retribution. This is an interesting finding which requires some comment. One might speculate that those who are less retributive are more oriented toward other people and that an interest in humanity leads to concern with social change. It may be that there is enough cynicism in the United States about our willingness or ability to undertake such change that commitment to change in itself leads to the opinion that violence is necessary to bring it about. In any case, the fact that low scores on the Retributive Justice Index are associated with high scores on the Violence for Social Change Index leads to the prediction that the student arrestees should score low on this Index. Table $\mathrm{X}$ shows this is the case. One might speculate that since the arrestees were less retributive than other college students, it is not likely that student protest is mainly due to displacement of hostile impulses, inasmuch as it seems reasonable to suppose that displacement of hostility would lead to positive attitudes toward retribution.

During the course of the interview, the respondent was asked to rank-order six values: freedom, equality, human dignity, respect for law, respect for property, and financial security. Those who chose freedom, human dignity, and equality as their three highest-ranking values were classified as "humanists"; those who chose respect for property, respect for law, and financial security as their three highest-ranking values were classified as "materialists." In addition, those who ranked equality last or second to last were classified as "materialists." This Index, the Humanism Index, accounted for $7 \%$ of the variance in the 
Table X. Percentage Responses to the Retributive Justice Index for Student Arrestees and College Students

\begin{tabular}{lccc}
\hline $\begin{array}{l}\text { Retributive } \\
\text { Justice Index }\end{array}$ & $\begin{array}{c}\text { Student arrestees } \\
(N=26)\end{array}$ & $\begin{array}{c}\text { College students } \\
(N=63)\end{array}$ \\
\hline Low & $1-2$ & 81 & 39 \\
High & $3-4$ & 19 & $\frac{14}{100 \%}$ \\
Total & $5-6$ & $100 \%$ & \\
$P<0.001$ & (Kolmogorov-Smirnov test). \\
\hline
\end{tabular}

Violence for Social Change Index among college-educated men in the national sample. Those who scored at the humanistic end of the Index were more inclined to think that violence was necessary to bring about social change than those who were more materialistic in orientation.

In a sense, it seems contradictory that men who are both educated and humanistically inclined should be likely to think that violence may be necessary for social change. After all, violence is destructive of property and persons irrespective of the cause in which it is used. It may be that education makes more apparent some of the unmet needs in American society, and so increases a feeling of need for social change. Or it may be that the educated are simply pessimistic about the willingness of society to bring about the changes needed in the absence of the pressure of violence. In any case, one would expect the student arrestees to be humanistically oriented. Table XI shows that the student arrestees were far more likely to have high scores on the Humanism Index than college students in the national sample.

Table XI. Percentage Responses to the Humanism Index for Student Arrestees and College Students

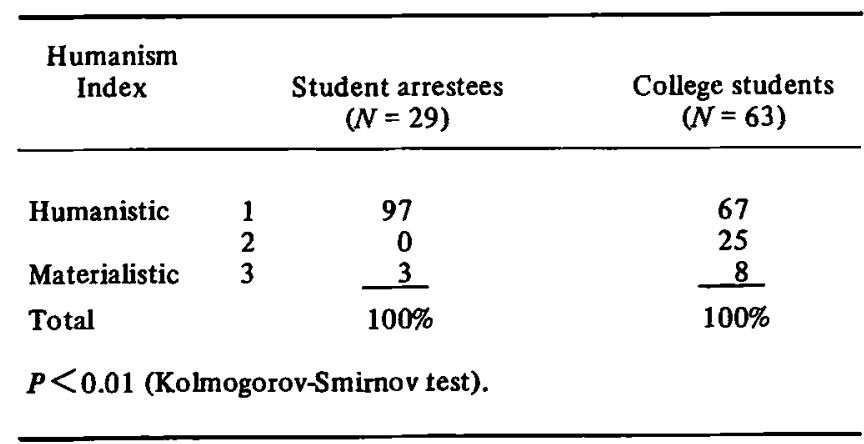


A related value, how people are valued relative to property, also accounted for some of the variance in the Violence for Social Change Index, although the association was weak for men with some college education. Nevertheless, the student arrestees were substantially more person-oriented than college students in our national sample (Table XII). Ninety-two percent of the arrestees fell in the most person-oriented category. The extent to which the student arrestees scored high on the two indices which are oriented toward humanistic values is impressive. The importance of people and how they live in contemporary society seems to be a major theme in their ideology.

There were a number of measures in the study which were not an integral part of the model. One of these was a personality scale measuring resentment and suspicion, the Resentment-Suspicion Index. Among college-educated men, the higher the individual scored on this Index, the more likely he was to think that violence was necessary to bring about a social change. These data would lead one to expect that the student arrestees would be more resentful and suspicious than college students in the national sample. However, this hypothesis was not confirmed by the data, and there was no trend in the anticipated direction.

This finding is particularly interesting since the Resentment-Suspicion Index might very well be regarded as a measure of frustration. Many workers

Table XII. Percentage Responses to the Property/Person Priority Index ${ }^{a}$ for Student Arrestees and College Students

\begin{tabular}{lccc}
\hline $\begin{array}{l}\text { Property/Person } \\
\text { Priority Index }\end{array}$ & $\begin{array}{c}\text { Student arrestees } \\
(N=26)\end{array}$ & $\begin{array}{c}\text { College students } \\
(N=61)\end{array}$ \\
\hline \multirow{3}{*}{ Property } & 1 & 0 & 7 \\
& 2 & 0 & 10 \\
Person & 3 & 8 & 24 \\
Total & 4 & $\frac{92}{100 \%}$ & $100 \%$ \\
$P<0.01$ (Kolmogorov-Smirnov test). \\
\end{tabular}

${ }^{a}$ The Property/Person Priority Index is based on responses to the questions:

1. Some people say that stealing or damaging property is as bad as hurting people. Others say that damaging property is not as bad as hurting people. What do you think?

2. Do you think it would be worse to become a permanent cripple, or to lose an uninsured home through fire, or are they equally bad?

The more person-oriented the individual, the higher was his score on the Index. 
regard frustration as a key component in the etiology of violence. Most recently, Berkowitz (1972) has stated that frustration may be regarded as an aversive stimulus leading to a generalized arousal which increases the possibilities of aggressive response. If frustration is a precursor of violence, these student arrestees did not demonstrate the point. It may very well be that the Resentment-Suspicion Index is not a good measure of frustration. It may also be that frustration is not necessarily a component of aggression. It is conceivable that there are two entirely separate motivations for violence directed at bringing about social change-first, a motivation created by the frustration of personal discomfort and necessity; second, a motivation based on ideological considerations which are humanistically oriented. There appears to be no compelling reason why frustration should be a necessary component in the latter, nor does there seem to be any overwhelming reason why there should be a unitary explanation for aggressive behaviors. It seems reasonable to suppose that the student arrestees, and other student activists, are motivated largely by ideological concerns. Thus, their predilection to violence may be motivated by instrumental rather than expressive considerations. That is, for some activists violence may be a way of achieving social goals. Other groups and individuals may use violence mainly as an expression of frustration. Nevertheless, the recognition of the possibility that some violence is generated as a way of accomplishing an end rather than as a way of expressing an emotion is an important one.

\section{DISCUSSION}

The primary purposes of this study were to provide some behavioral validation of our measures of attitudes toward violence for social change, to provide validation for our model of factors influencing attitudes toward violence, and to provide a framework for integrating the attitudes of student activists with the attitudes of other American men. Interpreting data collected from arrestees who have been returned to the community presents many methodological problems. Singer et al. (1970) point out that respondents may undergo substantial changes of opinion in the time lapse which occurs between the disturbance and the interview, so that attitudes investigated after a disturbance are not necessarily identical with attitudes prior to or during a disturbance. Moreover, arrestees are not necessarily typical of those involved in the disturbance, so that it is not reasonable to regard them as representative participants. In addition, one cannot assume that those arrested during a disturbance are necessarily those responsible for the violence which may have occurred. Nevertheless, it seems probable that there would be a larger proportion of individuals who had behaved violently among persons arrested in a disturbance involving violence than there would be in a national sample of 
respondents, so that there is some justification for using such a criterion group in a validation study.

As we had expected, the student arrestees held more favorable attitudes toward the use of violence for social change than did American college students generally. These data support the hypothesis that those who engage in violent behaviors are likely to favor violence of that type, thus providing some behavioral validation for the Violence for Social Change Index. There are other explanations of the data, however. It may be that positive attitudes toward the use of violence for producing social change are characteristic of students at the University of Michigan, albeit that seems somewhat unlikely. Even if such were the case, one would still have to recognize the fact that this university, like many of the more prestigious universities, had been more liable to "confrontationist politics" than many smaller, less well-known universities (Lipset, 1968). It is also not clear from these data whether the positive attitudes toward violence held by the student arrestees were attitudes held prior to the disturbance, or whether these were attitudes that developed afterward, perhaps as rationalization of their behaviors. Nevertheless, the fact remains that the predicted positive attitudes toward violence for social change were observed.

More interesting than the student arrestees' attitudes toward violence is their belief system. Part of this belief system was predicted by our model of factors influencing attitudes toward violence. Specifically, that model predicted that the arrestees should be strongly identified with protagonists in episodes involving violence used to produce social change, that they should hold negative attitudes toward the police, and that they should express strong beliefs in humanistic values. In addition, the model predicted that the student arrestees should be less likely than average to regard protest as a form of violence and more likely than other college students to believe that certain police behaviors are violent. These propositions are supported by the data, providing some substantiation for the model which predicted them.

Since one always likes to make inferences which go beyond one's data, it seems reasonable to ask to what extent the student arrestees interviewed are similar to other student activists. The demographic characteristics of these arrestees are what might have been anticipated from the literature. They were predominantly the children of remarkably well-educated families, and there was a substantial overrepresentation of those who claimed atheism or no religious preference. In addition, there was a small overrepresentation of Jews. These are precisely the characteristics which one would have expected on the basis of other studies. The one characteristic which did not conform to expectations derived from the literature on student activists was that of family income. The student arrestees were no better off financially than college students in the national sample. Although the characteristics on which we can directly compare the student arrestees with those of other activists are very limited, they suggest 
that this group of young people is probably similar to activists who have been studied elsewhere.

The norms of the student arrestees deviate substantially from those of college students in a national sample but are highly predictable from data on college-educated men in the United States. The student arrestees expressed serious doubts as to the essential worthiness of existing institutions. They were more apt to regard the courts as unfair and less apt to think favorably of government and business than were college students in the national population. These results are in keeping with the often repeated findings of social scientists that student activists are inclined to be cynical about many aspects of the existing social system (Morse and Peele, 1971).

The arrestees were far more humanistic and more inclined to value people in relation to property than were American college students generally. These findings not only conform to our general expectations based on data from men with a college education but also confirm the widely held idea (Keniston, 1968, Flacks, 1970; Lipset, 1968) that an important component of student activism is a humanistic orientation. In keeping with this idea is the finding that the student arrestees were less inclined to believe in retribution than were college students generally.

Our national data indicate that among college-educated men generally humanism is related to the belief that violence is necessary to bring about social change, so the association is not one which is idiosyncratic in the student group. Moreover, we have also found a strong belief in humanistic values among a small group of Chicanos with relatively little education who had been arrested after a street disturbance aimed at producing social change (Blumenthal and Jayaratne, 1972). Thus it seems that for many American men the belief that social change will not come about without the violence of property damage and personal injury is likely to be associated with a strong concern for humanistic values.

As predicted by our model of the justification of violence, the student arrestees were more identified with "white student demonstrators" and less identified with the police than were other college students. This supports our basic paradigm, that violence is justified by those who identify with the aggressors and who feel negatively about the implicit victims of that violence. Much has been made of attitudes toward the police in relation to black protest, but relatively little attention has been paid to this aspect of student confrontation (Nelson, 1970). Our data indicate that it is an important issue and that research on attitudes of student activists toward the police should be investigated further.

Lastly, the rhetoric of the student arrestees matches their ideology and their behavior. They are more likely to see violence in the actions of police than are other Americans, and they are less likely to define protest activities as violence. In addition, they are more apt to hold the ideological positions that 
violence is good, valuable, and necessary than are college students generally.

The belief systems of these students are coherent and understandable. They are not different from what was expected on the basis of data collected on college-educated adults. In fact, the ideology of the student arrestees represents little more than an extension of attitudes held by educated American men generally. These data indicate that the beliefs of student activists are only an exaggeration of attitudes that are generally held in the United States. This notion is in keeping with the literature on student activism, which implies that young activists are primarily transmitting the values of their parents (Braungart, 1971). Our data suggest that it is not only the values of their parents which they further; they are also transmitting the values of a whole generation.

\section{ACKNOWLEDGMENT}

Technical assistance with the analysis of these data was provided by Gerald A. Cole, who was also helpful in providing insightful comments on the manuscript.

\section{REFERENCES}

Berkowitz, L. (1972). Frustrations, comparisons, and other sources of emotional arousal as contributors to social unrest. J. Soc. Issues 28:77-91.

Blumenthal, M. D. (1972). Predicting attitudes toward violence. Science 176: 1296-1303.

Blumenthal, M. D., and Jayaratne, T. E. (1972). Attitudes toward violence for social change among a small group of persons arrested in a disturbance. Unpublished manuscript.

Blumenthal, M. D., Kahn, R. L., Andrews, F. M., and Head, K. B. (1972). Justifying Violence: Attitudes of American Men, Institute for Social Research, Ann Arbor, Mich.

Braungart, R. G. (1971). Family status, socialization, and student politics: A multivariate analysis. Am. J. Sociol. 77:108-130.

Campbell, A., and Schuman, H. (1968). Racial attitudes in fifteen American cities. In Supplemental Studies for the National Advisory Commission on Civil Disorders, Government Printing Office, Washington, D.C.

Clarke, J. W., and Egan, J. (1972). Social and political dimensions of campus protest activity.J. Politics 34: 500-523.

Flacks, R. (1970). Who protests: The social basis of the student movement. In Foster, J., and Long, D. (eds.), Protest: Student Activism in America, William Morrow, New York.

Flacks, R., and Mankoff, M. (1970). Revolt in Santa Barbara: Why they burned the bank. Nation, March 23, pp. 337-340.

Horn, J. L., and Knott, P. D. (1971). Activist youth on the 1960's: Summary and prognosis. Science 171: 977-985.

Keniston, K. (1968). Young Radicals, Harcourt, New York.

Keniston, K., and Lerner, M. (1971). Campus characteristics and campus unrest. Ann. Am. Acad. Pol. Soc. Sci. 395: 39-53.

Lipset, S. M. (1968). The activists: A profile. In Bell, D., and Kristol, I. (eds.), Confrontation: The Student Rebellion and the Universities, Basic Books, New York, pp. 4547. 
Mankoff, M., and Flacks, R. (1971). The changing social base of the American student movement. Ann. Am. Acad. Pol. Soc. Sci. 395:54-67.

Marx, G. T. (1970). Civil disorders and the agents of social control. J. Soc. Issues 26:19-57.

Morse, S. J., and Peele, S. (1971). A study of participants in an anti - Vietnam war demonstration. J. Soc. Issues 27:113-136.

Nelson, B. (1970). Kansas: Police-student violence imperils university. Science 169:567-569.

Report of the President's Commission on Campus Unrest (1970). Government Printing Office, Washington, D.C.

Rokeach, M. (1960). The Open and Closed Mind, Basic Books, New York.

Singer, B. D., Osborn, R. W., and Geschwender, J. A. (1970). Black Rioters, Heath Lexington Books, Lexington, Mass.

Watts, W. A., and Whittaker, D. (1966). Free speech advocates at Berkeley. J. Appli. Behav. Sci. 2:41-62.

Westby, D. L., and Braungart, R. G. (1966). Class and politics in the family backgrounds of student political activists. Am. Sociol. Rev. 31:690-692. 